\title{
Pengembangan Learning Management System (LMS) dengan Menerapkan Video Based Learning dan Gamification Dalam Meningkatkan Motivasi dan Keterlibatan Mahasiswa
}

\author{
Paradise*, Merlinda Wibowo \\ Fakultas Informatika, Program Studi Informatika, Institut Teknologi Telkom Purwokerto, Purwokerto, Indonesia \\ Email: 1,*paradise@ittelkom-pwt.ac.id, ${ }^{2}$ merlinda@ittelkom-pwt.ac.id \\ Email Penulis Korespondensi: paradise@ittelkom-pwt.ac.id
}

\begin{abstract}
Abstrak-Model pembelajaran yang digunakan sangat mempengaruhi proses pembelajaran di era pandemi Covid-19. Pembelajaran daring yang telah dilalui dalam satu tahun ini memicu rasa bosan karena dirasa terlalu monoton, intonasi yang kurang bervariasi, dan sulitnya untuk berinteraksi secara langsung dengan teman dan pengajar. Oleh karena itu, demi tercapainya proses pembelajaran yang efektif dan maksimal maka peneliti mengusulkan penggunaan metode video based learning dan metode gamification untuk meningkatkan pemahaman materi yang lebih dalam, motivasi dalam belajar, serta keterlibatan mahasiswa dalam proses pembelajaran melalui Learning Management System (LMS). Materi yang disampaikan akan diubah ke dalam bentuk video yang lebih interaktif dan menarik seperti video animasi sederhana, video tutorial, video podcast dan lainnya. Tujuan dari penelitian ini diharapkan dapat memberikan manfaat positif kepada mahasiswa untuk lebih berperan aktif dalam berdiskusi dan berkolaborasi serta bersemangat dalam mengerjakan seluruh aktivitas pembelajaran. Pengujian untuk mengukur tingkat motivasi dan keterlibatan ini dapat dilakukan dengan tiga tahapan, yaitu dengan pre-test dan post-test, T-Test dan data analitik dari akses mahasiswa pada LMS sesuai dengan indikator yang terlibat pada penelitian ini seperti video completion, total video, total comments, total badges dan completion of game level. Hasil dari penelitian ini menunjukkan terdapat pengaruh positif dari penerapan video based learning dan metode gamification pada LMS untuk meningkatkan motivasi dan keterlibatan mahasiswa.
\end{abstract}

Kata Kunci: Learning Management System; Video Based Learnin; Gamification; Motivasi; Keterlibatan

\begin{abstract}
The learning model used greatly affects the learning process in the Covid-19 pandemic era. The online learning that has been passed in this one year has caused boredom. The learning process is too monotonous, the teacher's intonation is less varied, and not easy to interact directly with friends and teachers. Therefore, to achieve an effective and maximum learning process, the researcher proposes using video-based learning and gamification methods to increase deeper understanding of the material, motivation in learning, and student involvement in the learning process through the Learning Management System (LMS). The material presented will be transformed into more interactive and interesting videos such as simple animated videos, tutorial videos, podcast videos, and others. This research aims to provide positive benefits for students to be more active in discussing and collaborating and enthusiastic in doing all learning activities. The test to measure the level of motivation and involvement can be carried out in three stages, namely with pre-test and post-test, T-test and analytical data from student access to the LMS according to the indicators involved in this study such as video completion, total video, total comments, total badges, and completion of the game level. This study result indicates a positive influence from the application of video-based learning and gamification methods on LMS to increase student motivation and engagement.
\end{abstract}

Keywords: Learning Management System; Video Based Learning; Gamification; Motivation; Engagement

\section{PENDAHULUAN}

Berkembangnya teknologi menjadi tantangan bagi para pengajar untuk bisa memanfaatkan sebaik mungkin teknologi yang ada. Salah satu pemanfaatan teknologi pada bidang pendidikan adalah pada model pembelajaran [1]. Model pembelajaran adalah strategi yang didapatkan dari teori penelitian yang rasional dan langkah-langkah serta tindakan yang dilakukan oleh mahasiswa dan tenaga pendidik [2]. Model pembelajaran yang digunakan sangat mempengaruhi proses pembelajaran yang berlangsung, terutama di era pandemi Covid- 19 seperti saat ini. Covid-19 merupakan penyakit akibat virus corona jenis baru yang muncul pada akhir 2019 pertama kali di Wuhan, Cina yang saat ini menyebabkan pandemi hampir di seluruh dunia. Gejala utama penyakit Covid-19 yaitu batuk, demam, dan sesak napas [3]. Terjadinya pandemi ini menyebabkan Pemerintah Indonesia pada bulan Maret 2020 mengeluarkan Peraturan Pemerintah Republik Indonesia nomor 21 tahun 2020 tentang pembatasan sosial berskala besar dalam rangka percepatan penanganan virus ini. Pandemi ini secara tidak langsung memaksa kita untuk merubah dari kebiasaan pembelajaran secara tatap muka langsung menuju pembelajaran secara online atau daring [4].

Pembelajaran daring merupakan sistem pembelajaran yang dilakukan dengan tidak bertatap muka secara langsung, tetapi menggunakan platform yang dapat membantu proses belajar mengajar yang dilakukan meskipun jarak jauh [5]. Salah satu platform pembelajaran daring yang digunakan adalah Learning Management System (LMS). LMS adalah suatu pengelolaan pembelajaran yang mempunyai fungsi untuk memberikan sebuah materi, mendukung kolaborasi, menilai kinerja siswa, merekam data peserta didik, dan menghasilkan laporan yang berguna untuk memaksimalkan efektivitas dari sebuah pembelajaran [6]. Penggunaan LMS ini mulai dilakukan oleh perguruan tinggi di berbagai wilayah di Indonesia. Model pembelajaran daring di masa pandemi Covid-19 ini memicu rasa bosan pada mahasiswa. Rasa bosan selama perkuliahan online bisa dirasakan karena terlalu monoton, intonasi yang kurang bervariasi, dan tidak dapat berinteraksi secara langsung dengan teman dan pengajar 
[5]. Selain itu sistem pembelajaran yang kurang efektif dapat menyebabkan penyampaian materi sulit untuk dipahami [7]. Selain itu, kurangnya motivasi dan keterlibatan mahasiswa terhadap proses pembelajaran [8]. Demi tercapainya pembelajaran yang lebih efektif dan maksimal maka peneliti melakukan penelitian penggunaan metode video based learning dan gamification pada proses pembelajaran daring ini.

Video based learning (VBL) adalah metode pembelajaran yang menggunakan video yang telah direkam untuk membantu dalam proses pembelajaran. Penelitian sebelumnya dilakukan oleh Maulida et al. [1] menyimpulkan bahwa video based learning memudahkan peserta didik dalam memahami materi dengan program video yang dapat diputar berulang-ulang dan video dapat digunakan ketika pendidik terdapat kendala dan mengharuskan pembelajaran dapat berlangsung sesuai pembelajaran. Penelitian selanjutnya dilakukan oleh [9] memberikan hasil bahwa penggunaan video based learning sebagai media belajar jarak jauh memiliki efek yang positif dan dapat meningkatkan kemampuan kognitif, meningkatkan kinerja belajar mengembangkan minat dan motivasi peserta didik serta peserta didik memiliki pemahaman yang lebih baik terhadap konsep pelajaran yang diajarkan.

Gamification adalah strategi pembelajaran yang menerapkan elemen-elemen game pada hal-hal yang bersifat non-game dengan tujuan mengikat dan memotivasi penggunanya untuk menyelesaikan suatu masalah (Wangi, 2019). Metode gamification memiliki beberapa elemen yaitu points, levels, leaderboards, badges, challenge, dan on boarding [8]. Penelitian mengenai gamification sebelumnya dilakukan oleh Winatha dan Ariningsih [10] bahwa penerapan gamification dalam pembelajaran memberikan manfaat positif kepada mahasiswa dimana mereka lebih berpartisipasi secara aktif dalam berdiskusi dan berkolaborasi, serta lebih bersemangat dalam mengerjakan seluruh aktivitas. Penelitian lain oleh [11] menyimpulkan bahwa tingkat kehadiran mahasiswa meningkat, nilai pretest dan postest memiliki kenaikan yang cukup baik, dan memiliki keterampilan sosial menggungkapkan pendapat, mengklarifikasi ide, mengkritik ide, dan mengungkapkan alasan.

Pada penelitian ini peneliti menggunakan metode gamifikasi dengan code.org sebagai media gamifikasinya. Code.org adalah suatu platform gamifikasi untuk belajar mengasah logika dalam ilmu komputer. Code.org bekerja dengan cara menyelesaikan satu persatu level yang ada. Penelitian ini bertujuan untuk mengetahui bagaimana pengaruh penggunaan metode video based learning dan metode gamification dalam proses pembelajaran daring dengan melalui LMS sehingga diharapkan mampu membangun minat mahasiswa dalam proses pembelajaran. Kedua pendekatan metode ini diharapkan membuat tampilan pada LMS lebih menarik dan menawarkan proses pembelajaran yang tidak monoton sehingga banyak disenangi oleh mahasiswa. Diharapkan mahasiswa lebih termotivasi untuk belajar dan juga lebih terlibat pada proses pembelajaran. Berdasarkan latar belakang diatas maka penulis melakukan penelitian dengan judul Penerapan Video Based Learning dan Gamification pada Learning Management System (LMS) untuk Meningkatkan Motivasi dan Keterlibatan Mahasiswa.

\section{METODOLOGI PENELITIAN}

Dalam metodologi penelitian terdapat penjelasan tentang alur kerja penelitian dan tahapan rencana penelitian yang dijelaskan untuk memberikan gambaran tentang bagaimana penelitian akan dilakukan selama periode penelitian. Bagan alur penelitian diilustrasikan pada gambar 1.

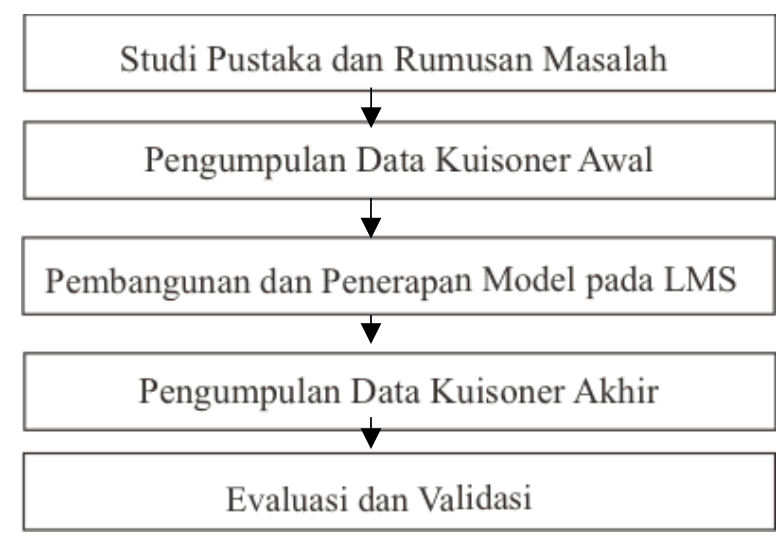

Gambar 1. Alur Penelitian

\section{a. Studi Pustaka dan Rumusan Masalah}

Studi pustaka adalah rangkain alur kegiatan yang berkaitan dengan metode pengumpulan data pustaka dan mengolah serta mencatat bahan penelitian [12]. Hal ini sangat penting untuk memberikan gambaran yang nyata untuk mendapatkan solusi yang tepat yang dapat menyelesaikan masalah penelitian ini. Tahap kepustakaan dalam penelitian ini berisi tentang definisi masalah, rumusan masalah, dan studi pustaka pada bidang terkait dan metode yang diusulkan seperti Video Based Learning dan Gamification. Video based learning (VBL) adalah metode 
pembelajaran yang menggunakan video yang telah direkam untuk membantu dalam proses pembelajaran. Gamification adalah strategi pembelajaran yang menerapkan elemen-elemen game pada hal-hal yang bersifat nongame dengan tujuan mengikat dan memotivasi penggunanya untuk menyelesaikan suatu masalah Penggunaan tinjauan pustaka dapat memberikan informasi dari peneliti-peneliti sebelumnya dan studi kerangka kerja dikumpulkan untuk dianalisis dalam membantu mengembangkan model pembelajaran baru untuk meningkatkan motivasi dan keterlibatan dari mahasiswa pada pembelajaran daring melalui LMS. Pada tahap ini diberikan hipotesis sebagai berikut:

\section{$\mathrm{H}_{0}$ : Tidak terdapat pengaruh penerapan video based learning dan metode gamification pada motivasi dan keterlibatan mahasiswa \\ $\mathrm{H}_{\mathrm{a}}$ : Terdapat pengaruh penerapan video based learning dan metode gamification pada motivasi dan keterlibatan mahasiswa}

\section{b. Pengumpulan Data Kuisoner Awal}

Teknik pengumpulan menggunakan metode survei dilakukan dengan cara menyebarkan kuisoner kepada responden [13]. Responden pada penelitian ini adalah mahasiswa mata kuliah Berpikir Komputasi Program Studi Informatika. Pengumpulan data ini digunakan untuk menilai bagaimana respon mahasiswa sebelum diterapkannya video based learning dan metode gamification pada LMS. Responden pada pengisian kuisoner awal ini sebanyak 40 orang mahasiswa.

\section{c. Pembangunan dan Penerapan Model pada LMS}

Pada tahap ini model pembelajaran secara daring dilaksanakan melalui LMS dan dibangun berdasarkan hasil studi pustaka serta rumusan masalah dari tahap sebelumnya. Pembelajaran daring ini sebetulnya dapat dilakukan dengan 2 metode yaitu sinkron dan asinkron [14]. Metode sinkron dilakukan secara live melalui room kelas virtual seperti live chat/blue button, sedangkan metode asinkron mahasiswa dituntut untuk belajar mandiri dengan mengikuti panduan yang telah disediakan pada LMS [15]. LMS adalah suatu pengelolaan pembelajaran yang mempunyai fungsi untuk memberikan sebuah materi, mendukung kolaborasi, menilai kinerja siswa, merekam data peserta didik, dan menghasilkan laporan yang berguna untuk memaksimalkan efektivitas dari sebuah pembelajaran. Pengembangan model ini dimulai dengan mendaftarkan mata kuliah terlebih dahulu pada LMS. Kemudian melakukan perancangan aktifitas pembelajaran yang akan dilakukan sampai dengan format penilaiannya. Pada langkah ini terdapat beberapa hal yang perlu diperhatikan seperti penyusunan Guidelines, Handbook atau PPT slides, Quiz dan Tugas, Daftar Permainan, Badges dan Penjelasannya serta Format Penilaian. Seluruh hasil dari penyusunan tersebut kemudian di upload ke LMS.

\section{d. Pengumpulan Data Kuisoner Akhir}

Pengumpulan data akhir dilakukan seperti pada pengumpulan data pada kuisoner diawal. Tahapan ini difungsikan untuk mengetahui bagaimana respon mahasiswa setelah diterapkannya video based learning dan metode gamification pada LMS. Responden pada pengambilan data akhir ini sebanyak 40 mahasiswa.

\section{e. Evaluasi dan Validasi}

Pada tahap ini dilakukan proses pemeriksaan model pembelajaran yang diusulkan dan membandingkannya dengan hipotesis sebelumnya. Evaluasi dilakukan untuk mengukur tingkat pencapaian keberhasilan secara akurat dan meyakinkan [16]. Hal ini digunakan untuk mengukur nilai motivasi dan keterlibatan mahasiswa setelah diterapkannya metode pembelajaran yang diusulkan dengan menggunakan metode video based learning dan gamification. Terdapat tiga tahap pengujian yang dilakukan yaitu dengan pre-test dan post-test, T-Test dan data analitik mahasiswa mengakses halaman LMS [17]. Pengujian ini diukur berdasarkan dari indikator penelitian yaitu video completion, total video, total comments, total badges dan completion of game level.

\section{HASIL DAN PEMBAHASAN}

Pada bab ini akan membahas mengenai hasil dan pembahasan dari penelitian yang telah dilakukan. Gambar 2 dibawah ini adalah gambar use case diagram. Use case diagram digunakan untuk menggambarkan fungsi apa saja yang ada pada sistem, termasuk peran aktor pada sistem tersebut. Aktor adalah pengguna yang ada pada LMS, yaitu mahasiswa dan dosen. Dosen dapat login pada LMS, dapat menambahkan materi, dapat membuat video, dapat membuat latihan soal, dan dapat mengatur gamification. Sedangkan untuk mahasiswa dapat login pada LMS, membaca materi, menonton video, mengerjakan latihan soal, dan memainkan permainan yang ada code.org. 
ISSN 2614-5278 (media cetak), ISSN 2548-8368 (media online)

Available Online at https://ejurnal.stmik-budidarma.ac.id/index.php/mib DOI 10.30865/mib.v5i3.3087

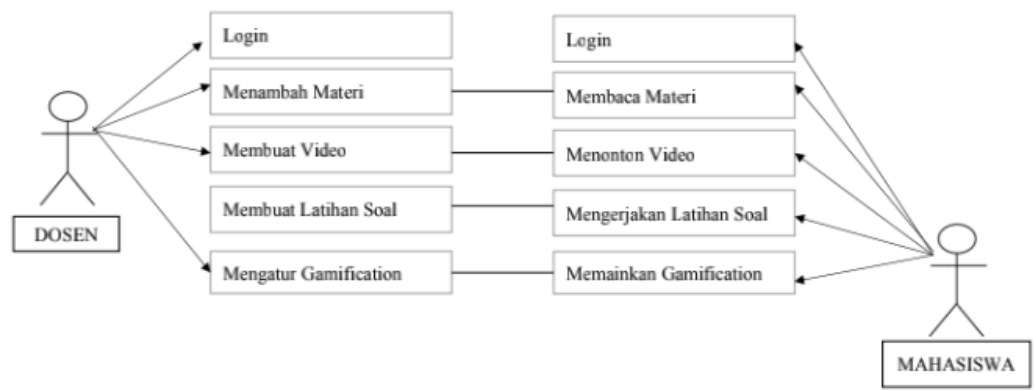

Gambar 2. Use Case Diagram

\subsection{Hasil Pengumpulan Data Awal}

Berikut pada gambar 2 adalah hasil survey nilai pre-test sebelum diterapkannya metode video based learning dan metode gamification pada LMS. Terdapat 40 orang mahasiswa yang menjadi responden pada pengumpulan data awal ini.

\begin{tabular}{||r|r|}
\hline \hline & PreTest \\
\hline 1 & 70,00 \\
\hline 2 & 55,00 \\
\hline 3 & 60,00 \\
\hline 4 & 70,00 \\
\hline 5 & 45,00 \\
\hline 6 & 50,00 \\
\hline 7 & 55,00 \\
\hline 8 & 60,00 \\
\hline 9 & 65,00 \\
\hline 10 & 60,00 \\
\hline
\end{tabular}

Gambar 3. Nilai Pre-Test

\subsection{Pembangunan dan Penerapan Model Pada LMS}

Gambar 3 merupakan penerapan pembangunan model pada LMS. LMS dapat kita modifikasi sesuai dengan kebutuhan masing-masing dosen. Pembangunan model pada penelitian ini dimulai dengan mengatur mata kuliah menjadi public agar mahasiswa dapat enroll ke dalam mata kuliah tersebut.

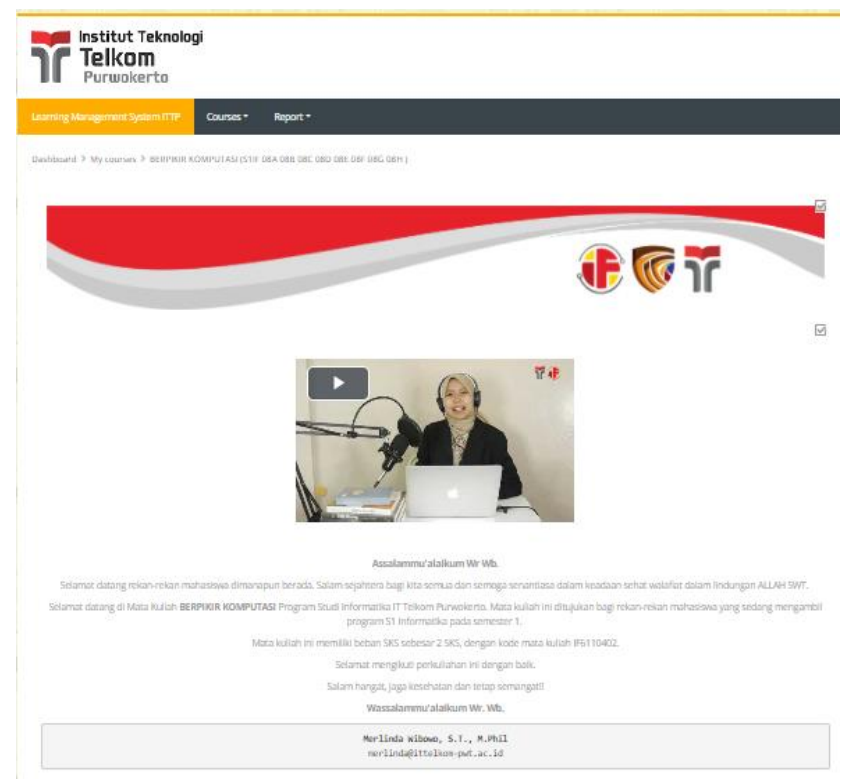

Gambar 4. Pembangunan Template LMS

Materi yang telah disusun kemudian dapat diubah ke dalam bentuk video interaktif seperti pada gambar 4 dengan durasi maksimal 15 menit. Hal ini diharapkan untuk menarik minat mahasiswa dalam memahami materi. Video yang dibuat dapat berupa video animasi sederhana, tutorial, podcast dan sebagainya. Selain dosen yang membuat video sebagai panduan atau tutorial, mahasiswa juga dilibatkan dalam pembuatan video materi lainnya 
ISSN 2614-5278 (media cetak), ISSN 2548-8368 (media online)

Available Online at https://ejurnal.stmik-budidarma.ac.id/index.php/mib DOI 10.30865/mib.v5i3.3087

dengan berupa video assignment. Jadi, dosen akan memberikan sub topik dan kemudian mahasiswa yang akan membuat video assignment agar ketika mahasiswa membuat video, maka dapat memotivasi dalam memahami materi. Selain itu, video hasil rekaman saat perkuliahan daring berlangsung juga dapat dibagikan kembali sehingga mahasiswa dapat lebih memahami dan memperdalam lagi materi yang disampaikan.

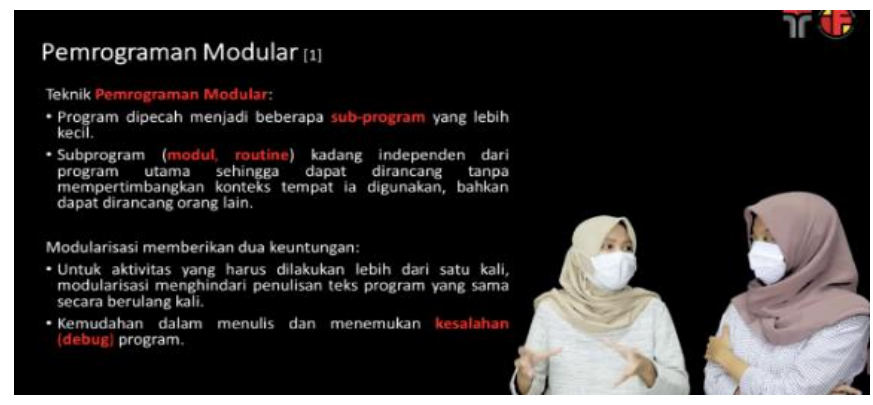

Gambar 5. Video Pembelajaran pada LMS

Langkah selanjutnya adalah penerapan metode gamification yang digunakan sebagai bentuk pendalaman materi selain dengan penugasan dan quiz. Pada metode ini terdiri dari beberapa elemen seperti daftar dari permainan, badges, leaderboard dan rewards. Permainan dapat disesuaikan dengan materi yang akan disampaikan seperti puzzle crosswords, match making dan sebagainya.

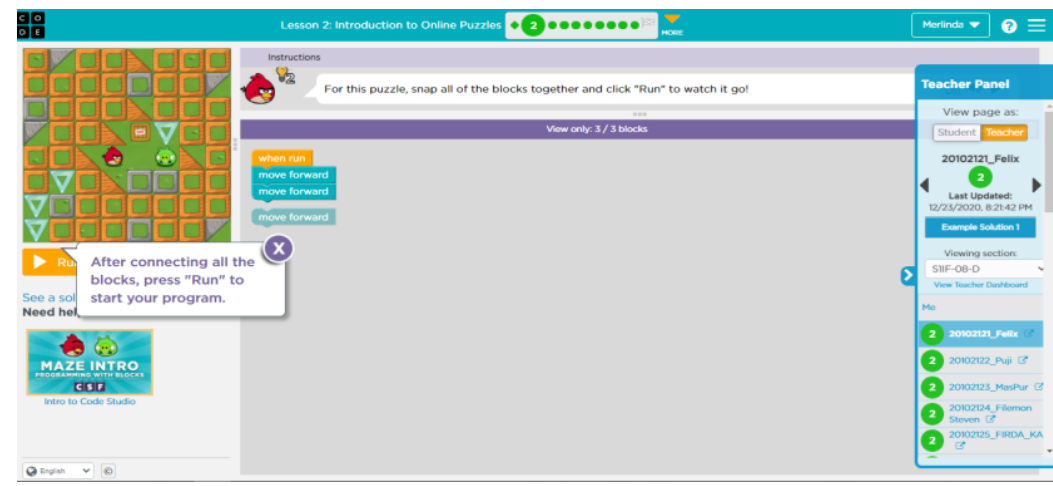

Gambar 6. Permainan pada Code.org

Gambar 5 memperlihatkan contoh permainan yang ada pada code.org untuk membantu dalam pemahaman Berpikir Komputasi. Setiap permainan tersebut akan ada completion levelnya untuk melihat sejauh mana mahasiswa terlibat ke dalam permainan tersebut. Gambar 6 menunjukkan completion level setiap mahasiswa.

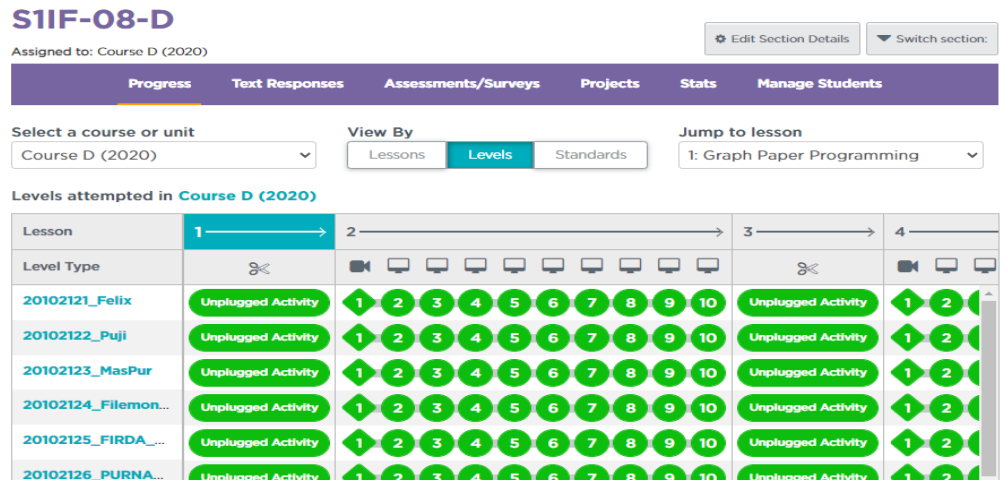

Gambar 7. Completion Level

Apabila mahasiswa telah menyelesaikan seluruh level permainan maka mahasiswa akan mendapatkan badges yang dapat berbentuk sertifikat atau pin sederhana. Disini mahasiswa dapat berlomba-lomba untuk mengumpulkan berbagai macam badges dari setiap topik pembahasan pembelajaran yang disusun. Setiap minggunya hasil dari pengumpulan badges ini akan dibuat ke dalam bentuk leaderboard. Siapa yang paling banyak dan paling cepat dalam mengumpulkan badges tersebut maka akan berada pada urutan tertinggi. Urutan leaderboard tertinggi nantinya akan mendapatkan reward dari pengajar dalam bentuk apapun, seperti voucher makan, voucher pulsa, poin tambahan dan sebagainya. Gambar 7 dibawah ini menunjukkan sertifikat yang didapat oleh mahasiswa ketika telah selesai melakukan seluruh level permainannya. 
ISSN 2614-5278 (media cetak), ISSN 2548-8368 (media online)

Available Online at https://ejurnal.stmik-budidarma.ac.id/index.php/mib DOI 10.30865/mib.v5i3.3087

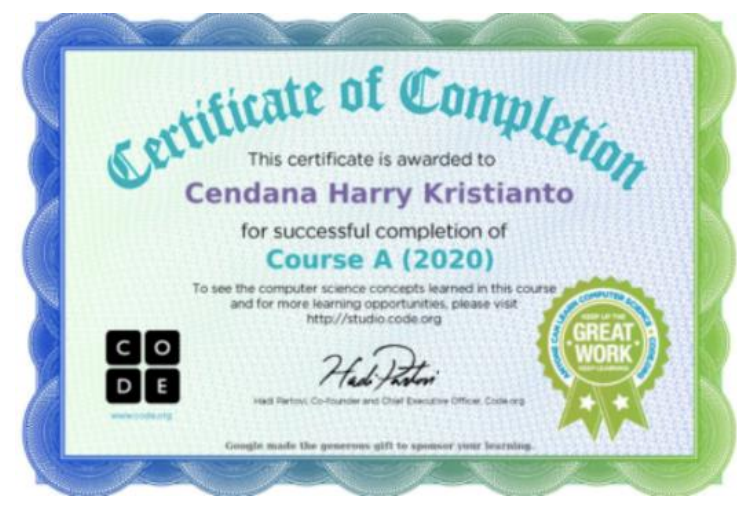

Gambar 8. Sertifikat Kompetisi

\subsection{Hasil Pengumpulan Data Akhir}

Sampel pada penelitian ini adalah mahasiswa-mahasiswi mata kuliah Berpikir Komputasi sebanyak 40 orang mahasiswa. Pada pengumpulan data akhir ini didapatkan nilai post-test mahasiwa setelah diterapkannya kedua metode tersebut. Pengumpulan data dilakukan dengan penyebaran kuisoner menggunakan google formulir. Gambar 8 memperlihatkan soal dan jawaban berbentuk skala likert.

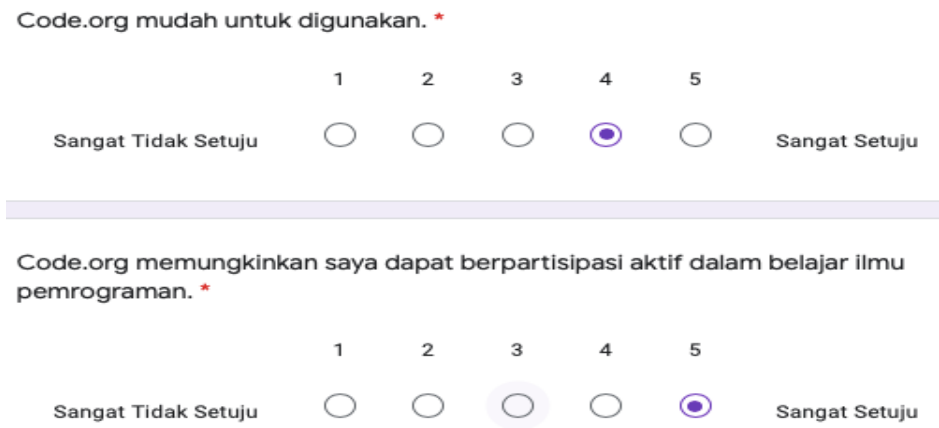

Gambar 9. Contoh Jawaban Kuisoner

\subsection{Evaluasi dan Validasi}

Pada tahap ini dilakukan evaluasi dan validasi dari hasil pengolahan data sebelumnya. Gambar 9 menjelaskan perbandingan hasil pengujian selisih nilai mean atau nilai rata-rata diantara nilai pretest dan nilai post-test.

\section{Paired Samples Statistics}

\begin{tabular}{lll|l|r|r} 
& & Mean & N & \multicolumn{1}{c}{$\begin{array}{c}\text { Std. } \\
\text { Deviation }\end{array}$} & \multicolumn{1}{c}{$\begin{array}{c}\text { Std. Error } \\
\text { Mean }\end{array}$} \\
\hline \multirow{2}{*}{ Pair 1 } & PreTest & 61,0000 & 40 & 10,01281 & 1,58316 \\
\cline { 2 - 7 } & PostTest & 87,1250 & 40 & 5,53399 &, 87500 \\
\hline
\end{tabular}

Gambar 10. Paired Sample Statistics

Pada output ini menunjukkan nilai rata-rata pre-test sebesar 61,00 , sedangkan rata-rata nilai pada post-test sebesar 87,12. Nilai standard deviaton atau standar deviasi pada pre-test menunjukkan angka 10,01 dan pada posttest sebesar 5,53. Sedangkan nilai std. error mean menunjukkan nilai 1,58 untuk pre-test dan 0,87 untuk nilai posttestnya. Berdasarkan hasil perhitungan nilai rata-rata mahasiswa diatas yaitu nilai pre-test 61,00 lebih kecil daripada nilai post-test 87,12 , sehingga dapat dikatakan bahwa terdapat perbedaan hasil belajar mahasiswa setelah diterapkannya video based learning dan gamification pada pembelajaran mata kuliah Berpikir Komputasi. Selanjutnya untuk melihat apakah perbedaan hasil pre-test dan post-test ini siginifikan atau tidak, makan perlu dilakukan uji paired samples t test seperti pada Gambar 10.

\section{Paired Samples Correlations}

\begin{tabular}{ll|r|r|c} 
& & N & Correlation & \multicolumn{1}{c}{ Sig. } \\
\hline Pair 1 & PreTest \& PostTest & 40 &, 134 &, 409 \\
\hline
\end{tabular}

Gambar 11. Paired Samples Correlations 
Gambar 10 memperlihatkan hasil uji hubungan antara variabel pre-test dengan variabel post-test. Nilai correlation atau nilai koefisien korelasi sebesar 0,13 dengan nilai signifikansinya (sig) sebesar 0,41. Berdasarkan output tersebut, maka diperoleh nilai signifikansi 0,41 lebih besar dari nilai probabilitasnya 0,05 , sehingga dapat disimpulkan bahwa tidak ada hubungan antara variabel pre-test dengan variabel post-test.

\begin{tabular}{|c|c|c|c|c|c|c|c|c|c|}
\hline & & & & aired Sam & es Test & & & & \\
\hline & & & & ired Differenc & & & & & \\
\hline & & & & & $\begin{array}{l}95 \% \text { Confider } \\
\text { the Dif }\end{array}$ & $\begin{array}{l}\text { Interval of } \\
\text { ence }\end{array}$ & & & \\
\hline & & Mean & Deviation & Mean & Lower & Upper & $\mathrm{t}$ & df & tailed) \\
\hline Pair 1 & PreTest - PostTest & $-26,12500$ & 10,77078 & 1,70301 & $-29,56966$ & $-22,68034$ & $-15,340$ & 39 &, 000 \\
\hline
\end{tabular}

Gambar 12. Paired Samples T-Test

Hasil output Paired Samples Test digunakan untuk menjawab hipotesis $\mathrm{H}_{0}$ dan $\mathrm{H}_{\mathrm{a}}$. Diketahui nilai signifikan (2-tailed) sebesar 0,00 lebih kecil dari nilai probabilitas 0,05. Sehingga dapat dikatakan bahwa ada perbedaan nilai rata-rata pada nilai pre-test dan nilai post-test. Hal ini menunjukkan bahwa hipotesis $\mathrm{H}_{0}$ ditolak dan $\mathrm{H}_{\mathrm{a}}$ diterima. Berdasarkan tabel output Paired Samples Test diatas diketahui t hitung bernilai negative yaitu sebesar -15,34. t hitung dapat bernilai negative karena nilai rata-rata pre-test lebih rendah daripada rata-rata nilai post-test. Dalam kasus seperti ini nilai t hitung negative dapat bermakna positif, sehingga nilai t hitung menjadi 15,34 .

Langkah selanjutnya adalah mencari nilai t tabel, dimana t tabel didapat berdasarkan nilai df (degree of freedom) yaitu 39 dan nilai signifikansi 0,025. Nilai tersebut menjadi acuan utuk mencari t tabel dan didapatkan nilai $\mathrm{t}$ tabel sebesar 2,02. Dengan demikian nilai t hitung 15,34 lebih besar dari t tabel 2,02, maka dapat disimpulkan $\mathrm{H}_{0}$ ditolak dan $\mathrm{H}_{\mathrm{a}}$ diterima yang artinya ada pengaruh penerapan video based learning dan gamification pada LMS untuk meningkatkan motivasi dan keterlibatan mahasiswa pada mata kuliah Berpikir Komputasi. Selain itu untuk memperkuat dari hasil hipotesis diatas, maka peneliti menambahkan bukti data analitik mahasiswa mengakses mata kuliah Berpikir Komputasi pada LMS. Gambar 12 menunjukkan grafik mahasiswa mengakses LMS selama satu semester, dimana terlihat bahwa ada kenaikan grafik mahasiswa mengakses LMS setelah ada penerapan video based learning dan gamification. Mahasiswa lebih termotivasi dalam belajar dan keterlibatan terhadap perkuliahan pun semakin meningkat pada saat pandemi ini.

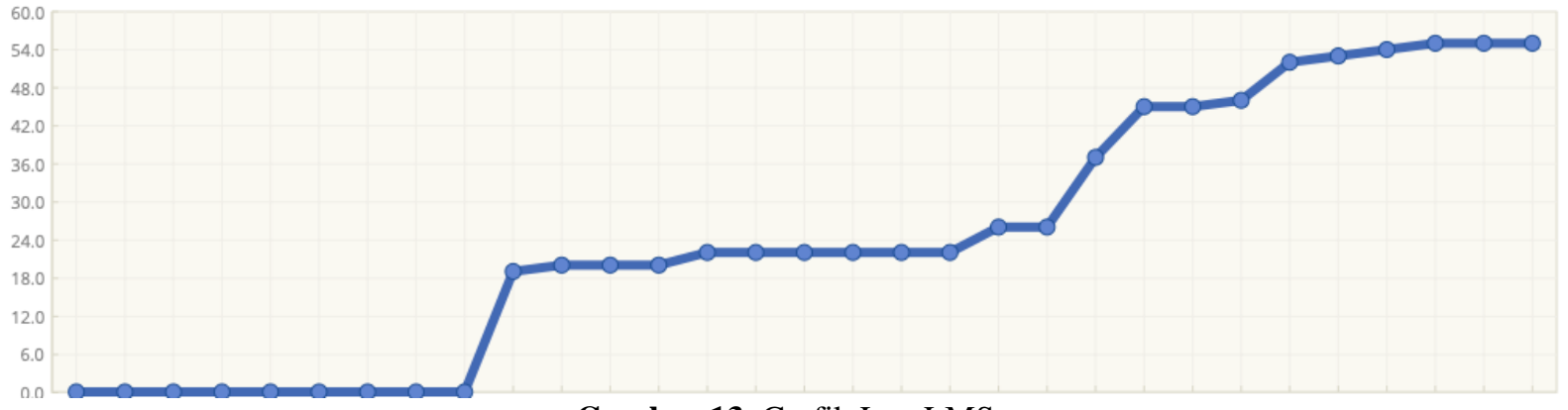

Gambar 13. Grafik Log LMS

\section{KESIMPULAN}

Setelah melakukan penelitian dengan menggunakan metode video based leaning berupa pembuatan video edukasi yang meanrik dan juga penerapan metode gamifikasi menggunakan code.org ini menghasilkan nilai tabel hitung 15,34 lebih besar dari t tabel 2,02, maka dapat disimpulkan $\mathrm{H}_{0}$ ditolak dan $\mathrm{H}_{\mathrm{a}}$ diterima, dimana yang dimaksud adalah ada pengaruh penerapan video based learning dan gamification pada LMS untuk meningkatkan motivasi dan keterlibatan mahasiswa pada mata kuliah Berpikir Komputasi. Selain itu sebagai penguat hasil uji t ini maka diberikan grafik log LMS pada mata kuliah tersebut yang menunjukkan grafik akses mahasiswa mengakses LMS semakin hari semakin meningkat.

\section{REFERENCES}

[1] H. Maulida, E. Putry, V. Nuzulul 'adila, R. Sholeha, and D. Hilmi, "Video Based Learning Sebagai Tren Media Pembelajaran Di Era 4.0," J. Pendidik. Ilm., vol. 5, no. 1, p. 2020, 2020.

[2] Sundari, "MODEL-MODEL PEMBELAJARAN DAN PEMEFOLEHAN BAHASA KEDUA/ASING," J. Pujangga, vol. 1, no. 2, pp. 106-117, 2015.

[3] M. K. Sari, "Sosialisasi tentang Pencegahan Covid-19 di Kalangan Siswa Sekolah Dasar di SD Minggiran 2 Kecamatan Papar Kabupaten Kediri,” J. Karya Abadi, vol. 4, no. 1, pp. 80-83, 2020.

[4] N. K. Mar'ah, A. Rusilowati, and W. Sumarni, "Perubahan Proses Pembelajaran Daring Pada Siswa Sekolah Dasar," Pros. Semin. Nas. Pascasarj. UNNES, 2020. 
[5] R. Pawicara and M. Conilie, "Analisis Pembelajaran Daring Terhadap Kejenuhan Belajar Mahasiswa Tadris Biologi," ALVEOLI J. Pendidik. Biol., vol. 1, no. 1, pp. 29-38, 2020.

[6] D. P. Pamungkas, "Ekstraksi Citra menggunakan Metode GLCM dan KNN untuk Identifikasi Jenis Anggrek (Orchidaceae)," Innov. Res. Informatics, vol. 1, no. 2, pp. 51-56, 2019.

[7] I. Vitasari, "Kejenuhan Belajar Ditinjau Dari Kesepian Dan Kontrol Diri Siswa Kelas Xi Sman 9 Yogyakarta," E-Journal Bimbing. dan Konseling Ed. 7 Tahun ke-5 2016 Masal., pp. 60-75, 2016.

[8] D. Amany and A. Desire, "Pembelajaran Interaktif berbasis Gamifikasi guna Mendukung Program WFH pada saat Pandemic Covid-19," ADI Bisnis Digit. Interdisiplin J., vol. 1, no. 1, pp. 48-55, 2020

[9] B. Nur, S. Nurdiana, and Nurhalwa, "Video Based Learning sebagai Media Belajar Biologi Jarak Jauh Masa Kini," Semin. Nas. Biol. dan Pembelajarannya Univ. Negeri Makassar, p. 229, 2019.

[10] K. R. Winatha and K. A. Ariningsih, "Persepsi mahasiswa terhadap penerapan gamifikasi dalam pembelajaran," $J$. Pendidik. Teknol. dan Kejuru., vol. 17, no. 2, pp. 265-274, 2020.

[11] Rusmaini, L. Sesriyani, and S. Anwar, "Penggunaan Model Pembelajaran Gamification Berbantuan Online Learning untuk Meningkatkan Kualitas Belajar Mahasiswa (Studi Pada Program RPL Daring Kemampuan Dasar Mengajar Universitas Pamulang - IKIP Gunung Sitoli),” J. Pendidikan, Hukum, dan Bisnis, vol. 6, no. 1, pp. 58-64, 2021.

[12] S. Supriyadi, "Community of Practitioners: Solusi Alternatif Berbagi Pengetahuan antar Pustakawan," Lentera Pustaka J. Kaji. Ilmu Perpustakaan, Inf. dan Kearsipan, vol. 2, no. 2, p. 83, 2017.

[13] A. Pratomo, "Analisa Pengaruh Partisipasi Dan Kepuasan Pemakai Terhadap Kinerja Dalam Pengembangan Sistem Informasi Berbasis Web di P3M Poliban,” J. Positif, vol. 3, no. 2, pp. 63-73, 2017.

[14] A. Kurniasari, F. S. P. Pribowo, and D. A. Putra, "Pendidikan guru sekolah dasar fakultas keguruan dan ilmu pendidikan universitas muhammadiyah surakarta 2013," J. Rev. Pendidik. Dasar J. Kaji. Pendidik. dan Has. Penelit., vol. 6, no. 3, pp. 1-8, 2020.

[15] C. E. J. Mamahit, "Pengaruh Pembelajaran Jarak Jauh Model Bauran Terhadap Hasil Belajar Dan Persepsi Mahasiswa [the Effect of the Blended Learning Model on Student Learning Outcomes and Perceptions]," Polyglot J. Ilm., vol. 17, no. 1, p. $67,2021$.

[16] I. L, "EVALUASI DALAM PROSES PEMBELAJARAN," J. Manaj. Pendidik. Islam, vol. 9, no. 2, pp. 920-935, 2019.

[17] J. Copriady, "PENERAPAN SPBM YANG DIINTEGRASIKAN DENGAN PROGRAM eXe LEARNING TERHADAP MOTIVASI HASIL BELAJAR MAHASISWA PADA MATA KULIAH KIMIA DASAR,” J. Pendidik., pp. 95-105, 2014. 